\title{
実時間ハイブリッド加振による弾塑性ダンパ支持配管の振動実験*
}

\author{
井上雅彦*1, 堀内敏彦*1, 浪田芳 郎*1
}

\section{Vibration Experiment of a Piping System Supported by Elastoplastic damper Using Real-Time Hybrid Excitation}

\author{
Masahiko INOUE, Toshihiko HORIUCHI and Yoshio NAMITA
}

\begin{abstract}
Hybrid experimental method, in which a vibration experiment using an actuator and a vibration analysis using a computer are simultaneously conducted by exchanging information with each other, is being developed as a new seismic experimental method. We developed a real-time hybrid experimental system using a hydraulic actuator with large excitation capacity and used it in a seismic experiment of an energy absorber. This absorber is a new type of pipe-support absorbing vibration energy by elastoplastic deformation. By comparing the results of the hybrid experiment with those of the shaking-table experiment, we showed that the results obtained by the two experi mental methods were close to each other. Therefore reliability of the developed hybrid experimental system was verified.
\end{abstract}

Key Words: Transient Response, Seismic Motion, Hydraulic Actuator, Hybrid Experimental Method, Elastoplastic Damper

\section{1. 緒 言}

地震による構造物の振動応答を調べるために，振動 台を用いた加振実験が従来より行われている。しか し，加振対象物が大形である場合には振動台の大きさ や性能によって, 構造物全体を加振することが困難に なる。そこで, 構造物の一部分を用いた加振実験と計 算機を用いた振動応答計算とをオンラインで結合して 行うハイブリッド実験が提案され，さまざまな研究が 行われている(1) (3)。この実験手法では, 数值計算を併 用することによって，構造物のうち注目する部分だけ を取り出して加振を行うことができる。その際, 加振 部分の振動挙動が速度や加速度に依存する場合には, 加振の時間軸を実際よりも伸ばして行う準動的な実験 方法では, 精度のよい評価が行えない。そのため, 加 振の時間軸と計算の時間軸とを合わせて, 実時間で実 験を行うことが必要となる。著者らはこの実時間ハイ ブリッド実験システムの開発を行って扔り, 油圧加振 機を一台使用した実験システムの開発を行ってき $た^{(4)-(6)}$.

* 原稿受付 1997 年 3 月 7 日.

*1 正員, (株) 日立製作所機械研究所( 300 土浦市神立町 $502)$.
本報告では，本実験システムの一適用例として，弾 塗性ダンパで支持された配管を対象とした実時間ハイ ブリッド実験について述べる。この弾塑性ダンパにつ いては，その振動特性を調べるため，配管を支持した 状態で振動台による加振実験 ${ }^{(7)}$ (以下，振動台実験と 呼ぶ）を既に実施しており，種々のデー夕を取得して いる。ここでは, 非線形特性を持つ弾塑性ダンパの油 压加振機による加振実験と, 配管系の線形の数值モデ ルによる振動計算とをオンラインで結合するという実 時間ハイブリッド実験を，試験条件を振動台実験に合 わせて実施した。そして, 得られた実験結果を振動台 実験結果と比較することにより，本実験システムの䒠 用性について示した。

\section{2. 実時間ハイブリッド実験の概要}

実時間ハイブリッド実験(以下，ハイブリッド実験 と呼ぶ)では，対象とする構造物のうち，注目する部分 のみを実際に加振し，その他の部分の振動灾答は数值 モデル化して計算機で振動解析を行う。これらの部分 構造モデルの加振実験と数值モデルの振動解析とをオ ンラインで結合し，応答を互いにやりとりしながら構 造物全体の振動応答を評洒する。ハイブリッド実験の 手法については文献 (4)に詳しく述べているが, 以下， 
図 1,2 を用いてハイブリッド実験の原理を簡単に述 ベる.

まず，モデル化について，図１に示す多層構造物を 例に述べる. 質量 $m_{i}$, 減衰 $c_{i}$, 剛性 $k_{i}(i=1,2, \cdots, n)$ を持つ多自由度系を実験対象として考え，そのうち， 耐震性を実証する必要がある部分や，非線形性が強く 数值モデル化が困難である部分などは実構造物の供試 体を作成し, 加振機に設置する(以下，この部分をハイ ブリッド要素と呼ぶ)，その他の部分は質量・減衰・ 剛性マトリックス, $M, C, K$ として数值モデル化し， 計算機に入力しておく.

次にハイブリッド実験の方法について図 2 に模式的 に示す.まず, 計算機で数值モデルの振動応答, すな わち, 微小時間後の相対変位ベクトル $x$ を, 波形発振 器から入力される地動加速度ベクトル $\ddot{q}$, 計測さ れたハイブリッド要素からの反力ベクトル $f$ を用い て次式の運動方程式に基づいて算出する。

$$
M \ddot{x}+C \dot{x}+K x=-M \ddot{q}+f
$$

次に, 計算機は計算結果をもとにハイブリッド要素 に生ずる変位を加振機へ指令信号として出力し, 加振 機によってハイブリッド要素に変形を与える。それに

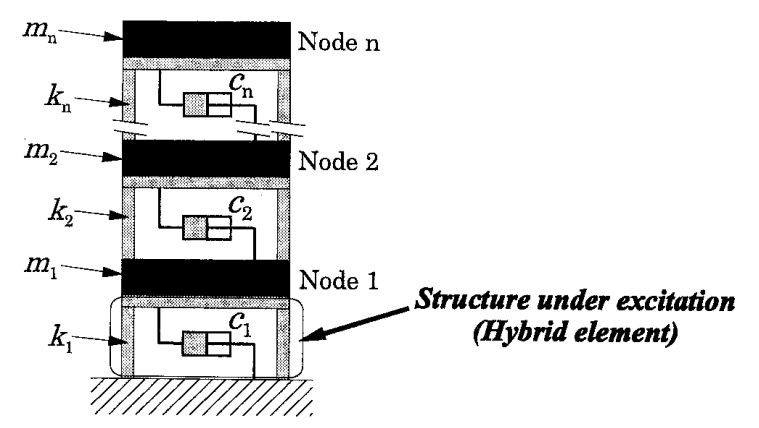

Fig. 1 Numerical model of multiple-degree-offreedom system

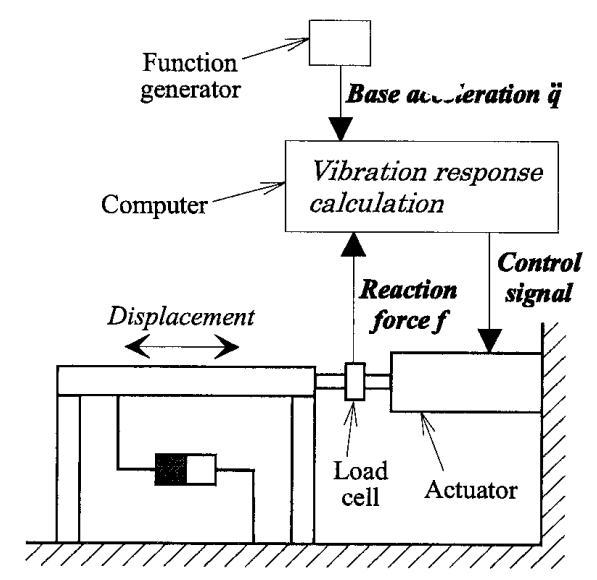

Fig. 2 Schematic of hybrid experiment
より生じるハイブリッド要素からの反力 $f$ をロード セルにより計測し，次ステップの地震入力 $\ddot{q}$ と合わ せて, 再び数値モデルの応答計算を行い, 微小時間後 の状態を求める，以上の過程を繰返し実施することに より,ハイブリッド要素と数值モデルの応答を組み合 わせて構造物全体の振動応答を評価する。この際, 加 振実験の時間軸と振動計算の時間軸を一致させて実時 間で実験を実施することにより，ハイブリッド要素に 含まれる減衰力や慣性力など時間依存性のある特性ま で高精度に評価することが可能になる。

\section{3. 実 験 方 法}

$3 \cdot 1$ 振動台実験の概要 ${ }^{(7)}$ 使用した弾塑性ダン パ(Energy Absorber, 以下, EAB と呼ぶ) は原子力発 電所や化学プラントなどの配管系を対象とした高減衰 配管支持装置の一つである。これは, 部材の弾塑性変 形による履歷特性を利用して, 支持した配管の振動工 ネルギーを吸収し制振効果を得るものである。

図 3 は比較の対象とした振動台実験の概略を示した 平面図であり, 以下，その条件および仕様について述 べる、配管は片端が固定支持，もう片端は自由という 片持ばりの境界条件下にあり，固有振動数を調整する ために自由端側に扔もり $(200 \mathrm{~kg})$ が取り付けられてい る. 配管の形状は外径 $89.1 \mathrm{~mm}$, 内径 $78.1 \mathrm{~mm}$ (呼び 径 $3 \mathrm{~B}$, 呼び厚さ $\mathrm{Sch} 40$ ), 全長 $4 \mathrm{~m}$ であり, 固定端 側から $3 \mathrm{~m}$ の位置が EABによって管軸と直角方向に 支持されている，供試体の加振方向は水平面内で管軸 に対して直角方向である.

図 4 に $\mathrm{EAB}$ の構造の概略を示す。 $\mathrm{EAB}$ はその両 端の相対変位により内部のX形の金属プレートが曲 げ変形を生じる構造になっており, 金属プレートの塑

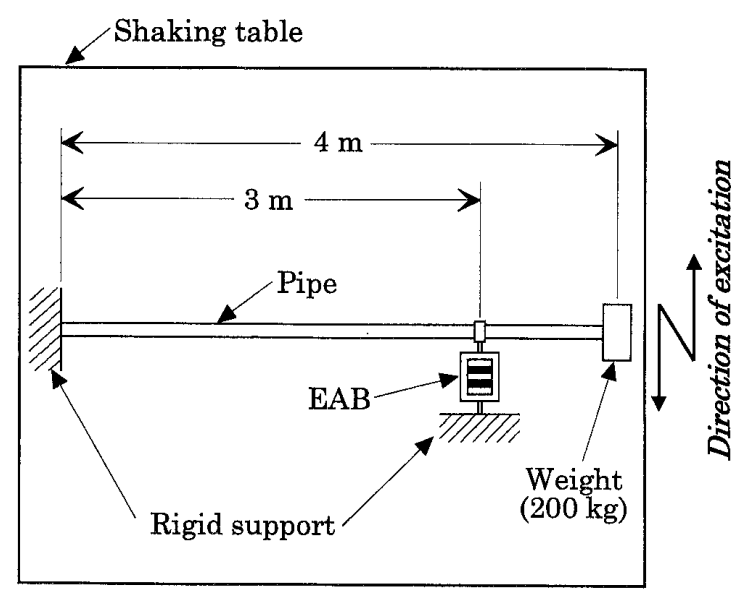

Fig. 3 Shaking-table experiment of a piping system supported by EAB (Plane view) 


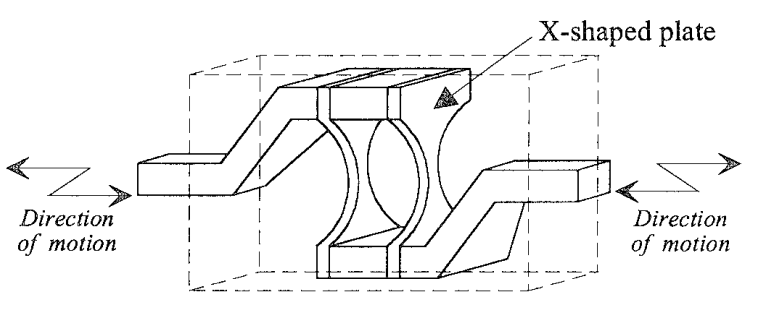

Fig. 4 Schematic of EAB

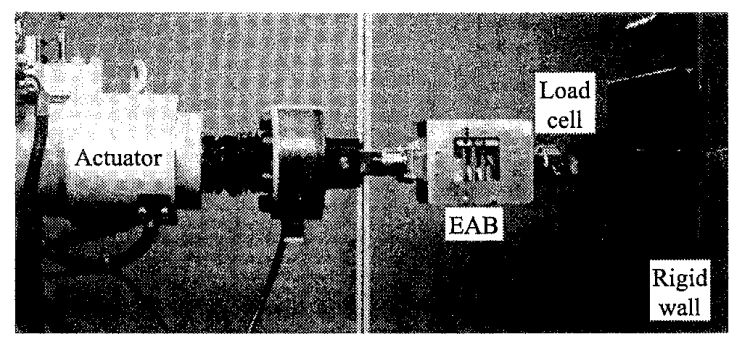

Fig. 5 Set-up of real-time hybrid experiment for the piping system

性変形を利用することで，支持した配管系の振動エネ ルギーを吸収する仕組みになっている。金属プレート をX形にしているのは，曲げに対する平板表面ひず みを均一にして塑性変形を一部に集中させないためで ある。本実験に使用した EAB が塑性変形を生ずる荷 重は $4.9 \mathrm{kN}$, 最大許容変位は土15 mmである。

このような振動台実験の試験条件に合わせて, 以下 に示す手順によって，EABで支持された配管系の八 イブリッド実験を行った。

$3 \cdot 2$ ハイブリッド実験の構成＼cjkstart前述のように八 イブリッド実験では詨象とする構造物のモデル化にお いて, 実際に加振を行う部分構造モデルと, 計算機で 振動解析を行う数值モデルとを併用する。本実験にお いては，図 5 に示すように，実験刘象のうち弾塑性変 形による非線形性を有するEAB を部分構造モデルと して, 油圧加振機 (最大加振力 $100 \mathrm{kN}$ ) と反力壁の間 に，荷重を計測するためのロードセルとともに取り付 ける。また，配管系を表1に示与定数を用いて有限要 素法によりモデル化し，固有值解析を行い図 6 に示す ような固有モードを求め，あらかじめ数值モデルとし て計算機に入力しておく。八イブリッド実験での数値 モデルの振動計算はモード空間において行った。な お, 表 1 にある $\mathrm{EAB}$ の剛性は $\mathrm{EAB}$ 省静的に微小変 形させ計測した值である。また, 数值モデルの振動解 析に用いる減衰の值は振動台実験において得られた配

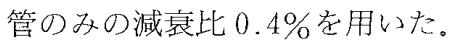

本実験系の構成を図 7 に示すが，この構成に即して 笑験手順を説明すると次のと扔りである。（1）地震入
Table 1 Parameters of numerical model of the piping system

\begin{tabular}{|c|c|c|}
\hline \multicolumn{2}{|c|}{ Young's modulus } & $192(\mathrm{GPa})$ \\
\hline \multicolumn{2}{|c|}{ Poisson's ratio } & 0.3 \\
\hline \multicolumn{2}{|c|}{ Density } & $7850\left(\mathrm{~kg} / \mathrm{m}^{3}\right)$ \\
\hline Diameters & out side & $89.1(\mathrm{~mm})$ \\
\hline & inside & $78.1(\mathrm{~mm})$ \\
\hline \multicolumn{2}{|c|}{ Sectional area } & $14.45\left(\mathrm{~cm}^{2}\right)$ \\
\hline Moment of inertia of area & $126.7\left(\mathrm{~cm}^{4}\right)$ \\
\hline \multicolumn{2}{|c|}{ Section modulus } & $\left.28.44(\mathrm{~cm})^{3}\right)$ \\
\hline Linear stiffness of EAB & $2.78(\mathrm{MN} / \mathrm{m})$ \\
\hline
\end{tabular}

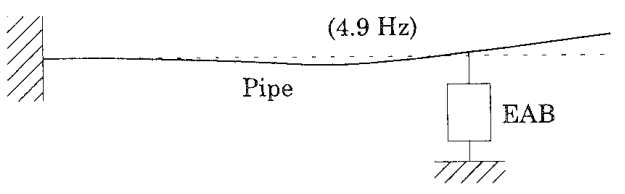

Fig. 6 First eigen mode of the pipe supported by EAB

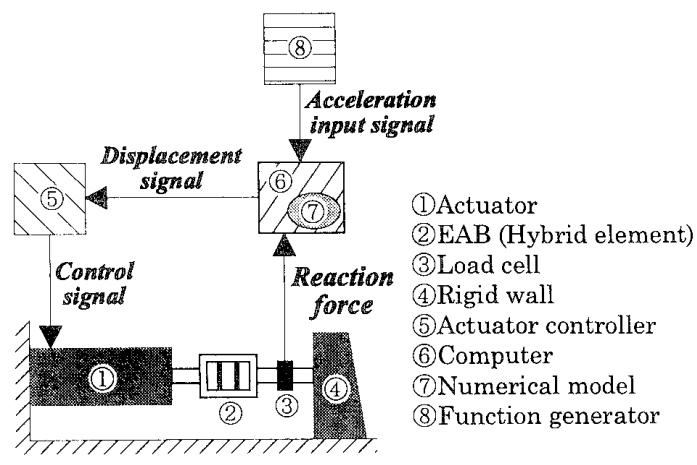

Fig. 7 Schematic of the hybrid experiment

力が加わった際の配答系の応答のうち $\mathrm{EAB}$ 部分の応 答変位を加振機により実現し，(2) そ扎によって生じ る $\mathrm{EAB}$ からの反力をロードセルにより計測し，(3) 計測した $\mathrm{EAB}$ 反力と波形発振器から逐次入力される 地震加速度とから数值モデルの振動応答計算を計算機 で行い, (4)この結果をもとに計算機から加振機制御 盤に変位信号を出力し，（5）加振機制御盤により加振 機を変位制御によって動作させる。以上の過程を高速 に繰り返すことによって振動実験を行う。本実験では 反力の取り込みと加振機動作の繰返しを $0.5 \mathrm{~ms}$ ごと に行った。

\section{4. 実験結果の比較}

4・1 実験項目振動台実験で用いられた正弦波 掃引抏よび地震波を使用して同様の加振害験を実施 し, 振動台実験結果との比較, 検討を行う。 
まず, 正弦波掃引により配管系の共振点の確認およ び入力の増加に伴う配管系の振動伝達特性の変化につ いて調べた，次に，周波数特性の異なる 2 種類の地震 波を用いて，それらの入力振幅を段階的に増加させな がら加振を繰返し笑施し, 応答波形や最大振幅の変化 について調べた. 使用した地震波は人工波(卓越振動 数を配管系の線形固有振動数付近に設定した人工地震 波)，およびEI Centro 波(1940 年の Imperial Valley 地震の南北方向観測波)の 2 種類である.それぞれの 地震波の特性を表す応答スベクトルを図 8 に示す.図 8(a) は人工波の加速度応答スペクトルを 3 とおりの 減衰比について示したものであり, $5 \mathrm{~Hz}$ 付近にピー クを持っており, 配管系の微小振動時の固有振動数に 合致したものとなっている. 同様に, 図 $8(\mathrm{~b})$ に示し たものは El Centro 波の加速度応答スペクトルであ り，人工波に比べると主要な周波数成分がより広い範 囲に広がっている。

測定を行う項目は入力加速度と, $\mathrm{EAB}$ の変位扔上 び反力(圧縮方向を正とした)である. EABの変位は 加振機に内蔵された変位計により検出し, 反力は $\mathrm{EAB}$ と剛壁の間に設置したロードセルによって測定 した。また，数值モデルにより配管各部の応答が算出 されるので, 配管先端の加速度応答についても振動台 実験との比較のためデータの収録を行った。

$4 \cdot 2$ 正弦波掃引 $\mathrm{EAB}$ は前述の上うに金属の弾 塑性変形を利用しており非線形応答特性をもつ.そこ で, 応答の振幅依存性を確認するために, 数段階の入

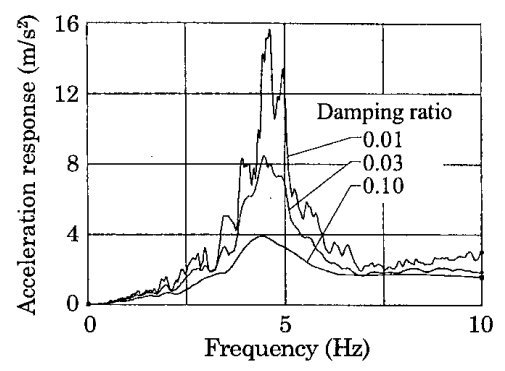

(a) Artificial wave

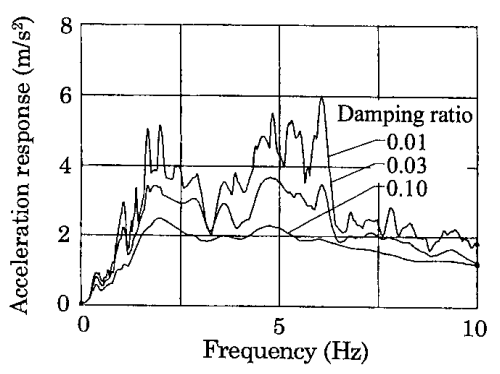

(b) El Centro wave

Fig. 8 Response spectrum of earthquake
力振幅に扔いて正弦波掃引実験を行った，以下，その 結果について述べる。

図 9 (a) は八イブリッド実験で得られた配管先端の 振動伝達特性である。これは，入力加速度に対する配 管先端の絶対加速度の応答倍率を表しており, 入力の 加速度振幅が $0.5 \mathrm{~m} / \mathrm{s}^{2}$ から $5.0 \mathrm{~m} / \mathrm{s}^{2}$ までの 4 段階に ついて示した。な拉，ハイブリッド実験における配管 先端の加速度值は加振実験と同時に行われる振動計算 から得られるものである.小振幅の入力では $\mathrm{EAB}$ 弾性剛性での配管系の共振点近傍で振動伝達特性に顕 著なピークが現れている．入力振幅が大きくなるに従 って，応答倍率の最大值が小さくなると同時にはっき りとしたピークが見られなくなる。また，塑性変形に よる剛性の低下によって共振点が低振動数側へ移行し ている、比較のため, 図 $9(\mathrm{~b})$ に振動台実験に沶いて 得られた結果を示す．入力振幅が小さい場合には微小 なガタなどの影響により応答倍率の大きさに差が見ら れるものの, 入力振幅の増加に伴う応答倍率の低下, 共振点の変化などは同様な傾向を示しており, 振動台 実験で得られた EAB 支持配管系の振動特性を再現し ていることがわかる。

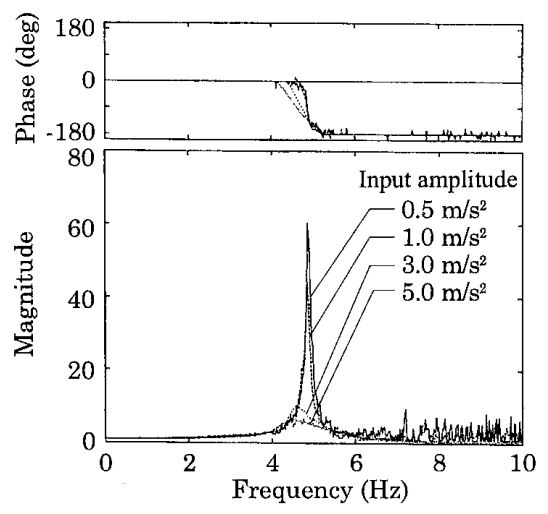

(a) Hybrid

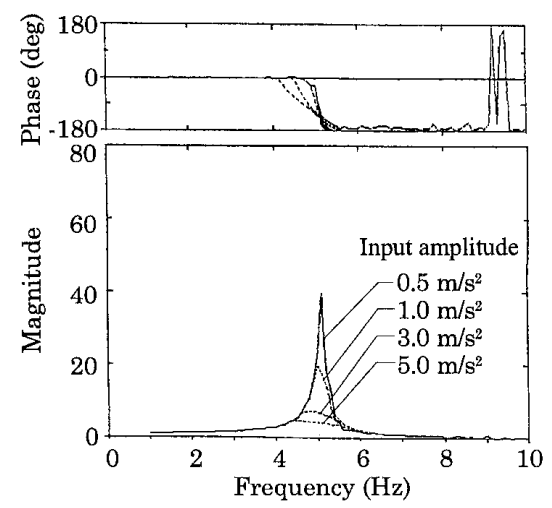

(b) Shaking table

Fig. 9 Acceleration transfer function of response of the top of the pipe 


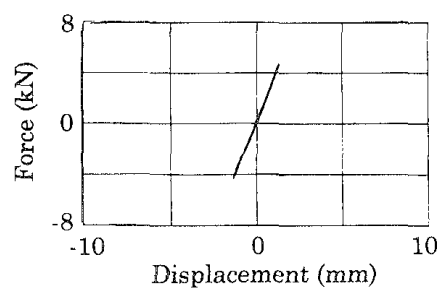

(a) Input amplitude $0.5 \mathrm{~m} / \mathrm{s}^{2}$

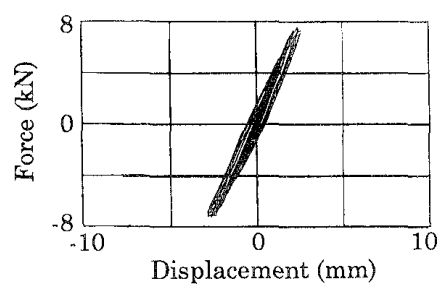

(b) Input amplitude $1.0 \mathrm{~m} / \mathrm{s}^{2}$

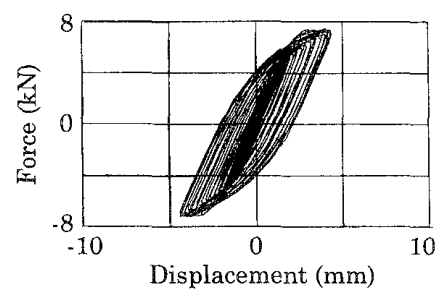

(c) Input amplitude $3.0 \mathrm{~m} / \mathrm{s}^{2}$

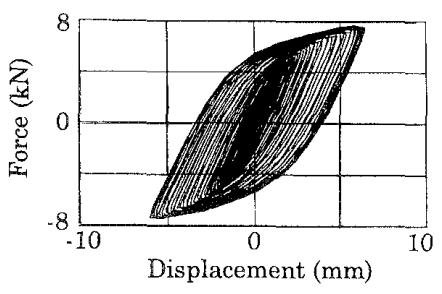

(d) Input amplitude $5.0 \mathrm{~m} / \mathrm{s}^{2}$

Fig. 10 Variation of relation between force and displacement obtained from sweep excitation in hybrid experiment

また，図 10 はハイブリッド実験の正弦波掃引にお いて, EAB の変位一汃履歴特性が入力振幅の大き さに応じて，どのように変化したかについて表したも のである。図 10(a)に示卞加速度振幅 $0.5 \mathrm{~m} / \mathrm{s}^{2}$ の小 振幅入力では, $\mathrm{EAB}$ の応答恃弾性域にあるため, 変位 と反力の間にほほ線形の関係が見られる。しかし，図 $10(b) \sim(d)$ に示すように入力振幅が大きくなるに従 って $\mathrm{EAB} の$ 応答も大きくなり, その変形が塑性域に 入るため, 変位振幅の大きな部分で変位の増加に対す る反力の増分が減少し，応答全体としてヒステリシス ループを描くようになる。このループで囲まれる面積

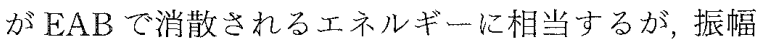
の増加とともにループの面積が大きくなり， $\mathrm{EAB} の$ 塑性変形による減衰效果が増加していることがわか

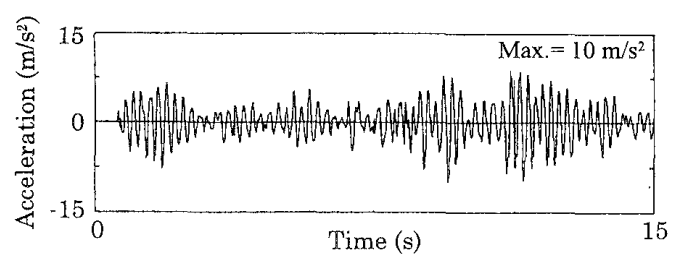

Fig. 11 Input acceleration of artificial wave

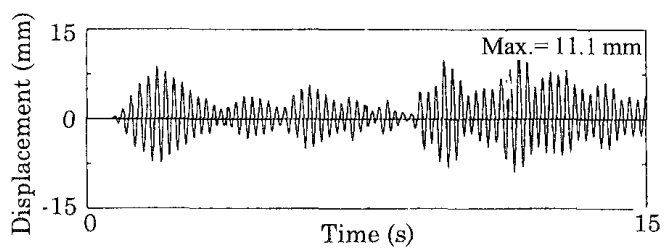

(a) Time history of displacement

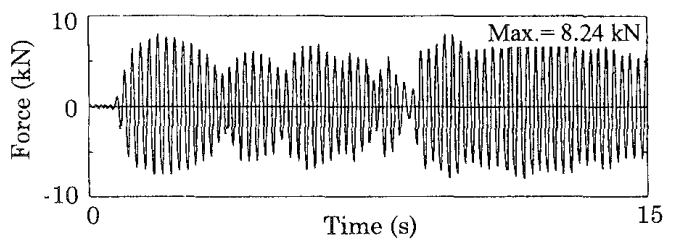

(b) Time history of force

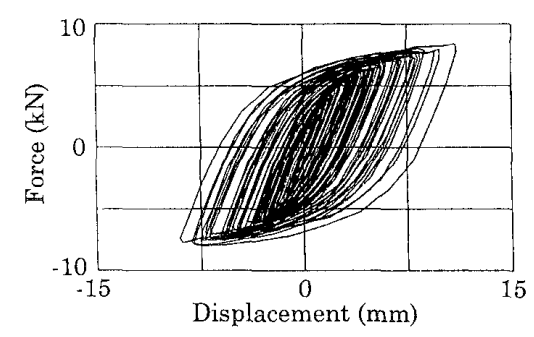

(c) Relation between displacement and force

Fig. 12 Response of EAB to artificial wave (Hybrid)

る。この効果は, 配管先端の応答倍率が入力の増加と ともに減少することに現れており，加振によって $\mathrm{EAB}$ に生じるこのような荷重-変位特性が, ハイブリ ッド実験に扔いて適切に数值モデルの計算に反映され ることによって, 図 9(a)のような配管系の伝達特性 が得られた。

\section{$4 \cdot 3$ 地震波加振}

$4 \cdot 3 \cdot 1$ 人工波加振人工波は図 $8(a)$ に示した ようにその卓越振動数が, $\mathrm{EAB}$ が弾性を示守線形応 答範囲での固有振動数付近にある波であり，その加速 度波形を図 11 に示す。この波形について加振レベル を段階的に増加させながら繰返し加振を行った。この うち，図11に示した最大振幅を $10 \mathrm{~m} / \mathrm{s}^{2}$ とした場合 の入力に対する $\mathrm{EAB} の$ 変位, 反力の時刻歴波形と, それらを変位一取力の関係で表したものを図12(a) 
〜 (c)に示す. 図 12(a)に示す応答波形の振幅の変 化の様子は概小入力波形と同様であるが，図 12 (b)に 示す反力では変位に比べると振幅の変動が緩やかであ る。これは変位が大きな部分では EAB のプレートの 変形が塑性域に達しているため, 変位の増加に対して 反力がそれほど增えないためである。このことは図 12(c)に示すように $\mathrm{EAB}$ の応答がヒステリシスルー プを描いていることからもわかる。

比較のため，振動台実験において，同じく人工波の 最大振幅が $10 \mathrm{~m} / \mathrm{s}^{2}$ で入力を行った際の EAB の変位 および反力の時刻歴波形と同時間内の変位一反力の関 係を図 13(a)〜 (c) に示す. 振動台実験では供試体 に加わる加速度人力は振動台特性の影響を受けたもの であるため, ハイブリッド実験で数值モデルに加えた 入力と厳密には一致していないが, 図 12 と図 13 を対 比してみると, ハイブリッド実験による応答は振動台 実験のものと波形が近似していることが確認できる。 さらに，両実験結果について，入力した人工波の加速 度振幅と $\mathrm{EAB}$ の最大応答の関係を比較したものを図

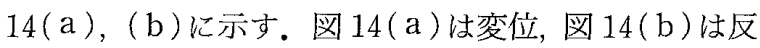
力について，いずれも入力の最大加速度に対する最大 応答值を示したものである，図中の○印が振動台実験

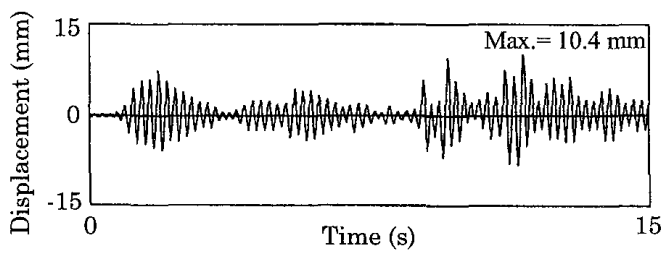

(a) Time history of displacement

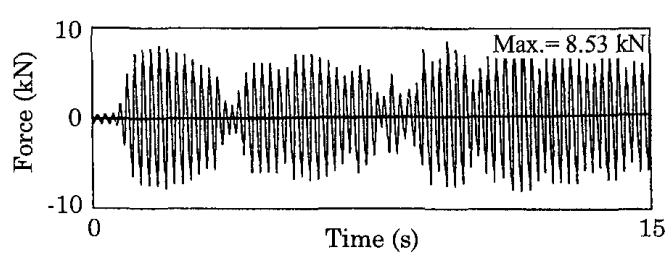

(b) Time history of force

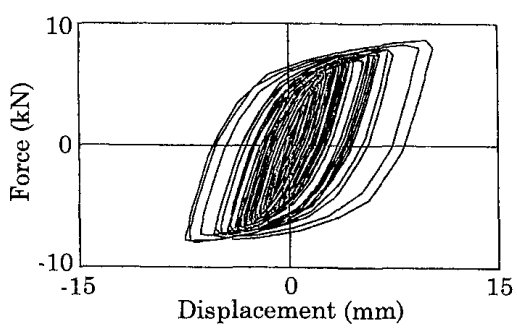

(c) Relation between displacement and force

Fig. 13 Response of EAB to artificial wave (Shaking table)
結果， $\triangle$ 印がハイブリッド実験結果を示しており，変 位, 反力ともその最大值は振動台実験とハイブリッド 実験とでほぼ等しい值が得られている。

$4 \cdot 3 \cdot 2 \mathrm{El}$ Centro 波加振 次に, El Centro 波を 入力として, 人工波加振と同様に加振レベルを段階的 に増加させながら加振を行った。 そのうち, 最大振幅 を $10 \mathrm{~m} / \mathrm{s}^{2}$ に設定した際の El Centro 波の加速度波形 を図 15 に示す。この入力に対してハイブリッド実験 で得られた EABの変位および反力の応答波形と，同 時間内での $\mathrm{EAB} の$ 変位一反力の履歴を図 $16(\mathrm{a})$ $\sim(\mathrm{c})$ に示す.

比較のため，振動台実験において同じく最大振幅 10 $\mathrm{m} / \mathrm{s}^{2}$ の El Centro 波で加振を行った際の, EAB の変 位及び反力の応答波形とそれらを変位-反力の関係で 表したものを図 $17(\mathrm{a}) \sim(\mathrm{c})$ に示す. 両実験結果に おいて，最大応答は加振直後の大きな入力加速度が加

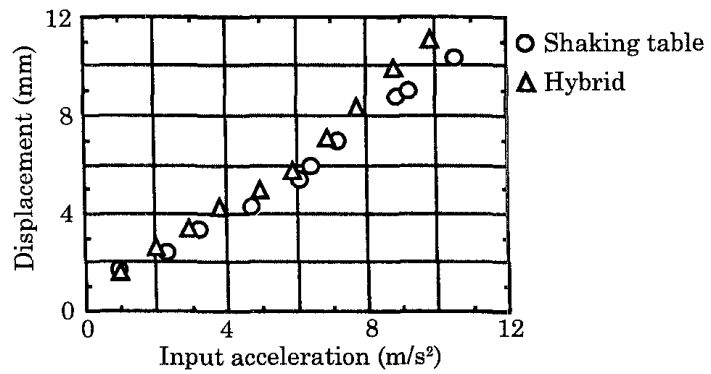

(a) Relation between input acceleration and displacement of $\mathrm{EAB}$

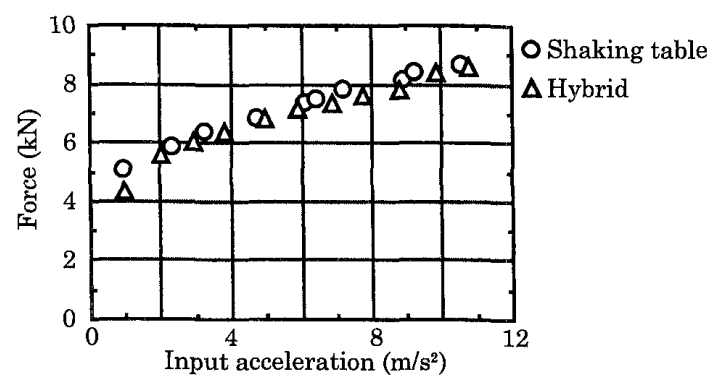

(b) Relation between input acceleration and reaction force of $\mathrm{EAB}$

Fig. 14 Comparison of EAB responses obtained from two experimental methods (Artificial wave)

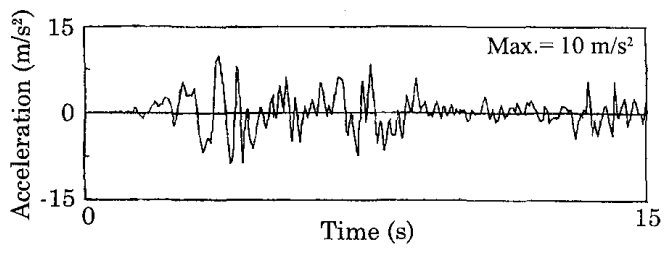

Fig. 15 Input acceleration of El Centro wave 


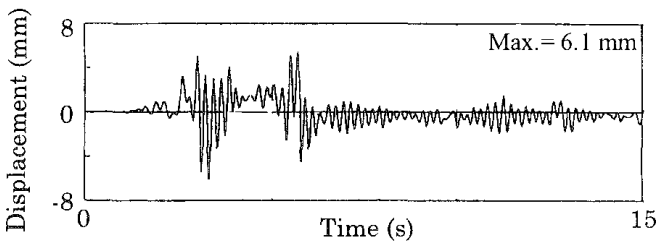

(a) Time history of displacement

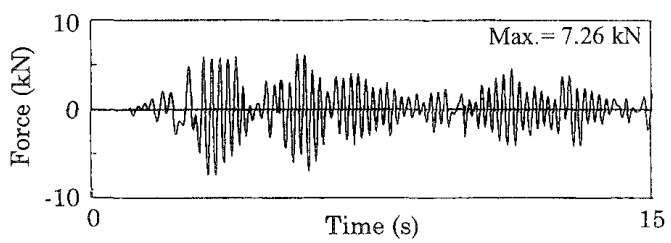

(b) Time history of force

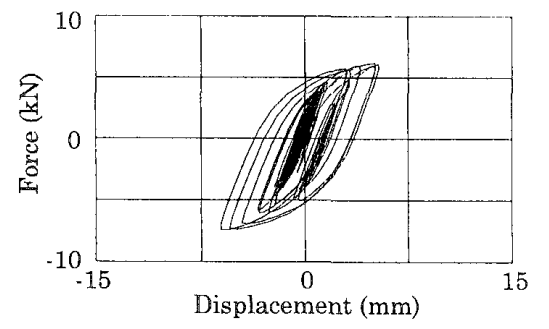

(c) Relation between displacement and force

Fig. 16 Response of EAB to El Centro wave (Hybrid)

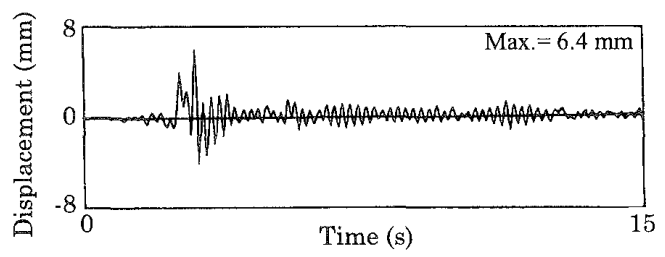

(a) Time history of displacement

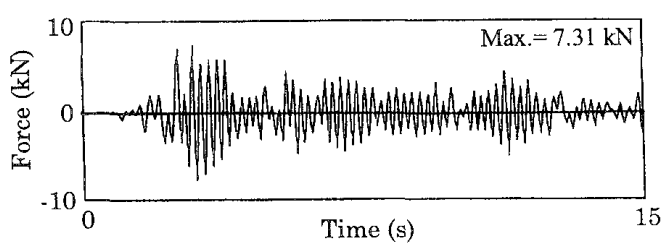

(b) Time history of force

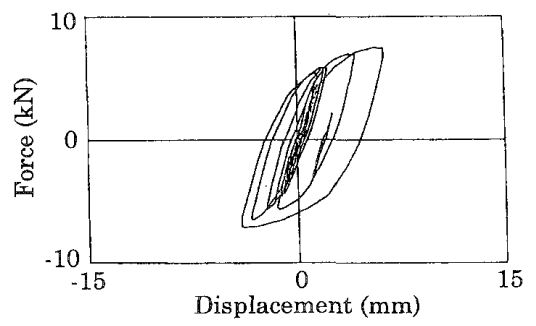

(c) Relation between displacement and force

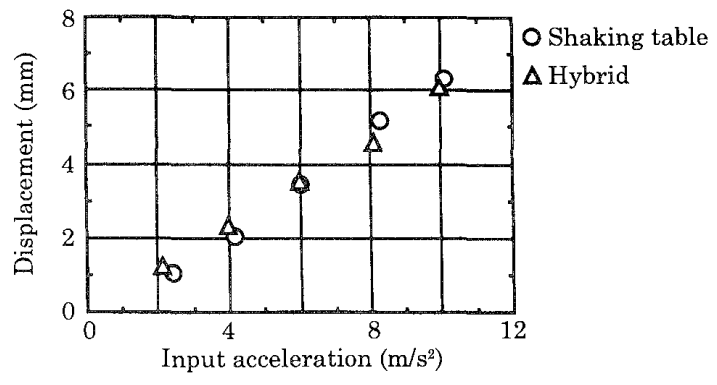

(a) Relation between input acceleration and displacement of $\mathrm{EAB}$

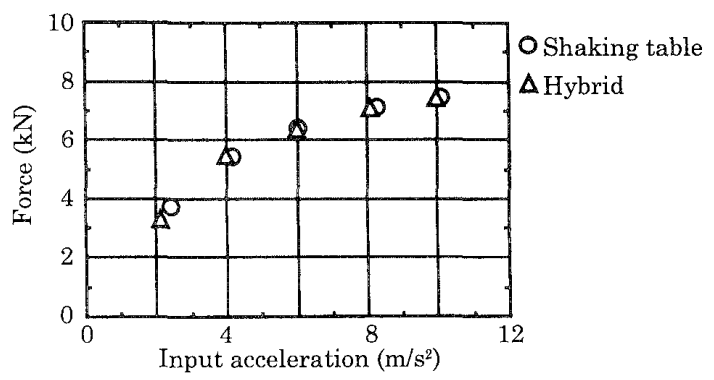

(b) Relation between input acceleration and reaction force of $\mathrm{EAB}$

Fig. 18 Comparison of EAB responses obtained from two experimental methods (El Centro)

わったときに生じている。その後, 全体的に応答は溸 減するが，八イブリッド実験では 5 秒付近で振動台実 験に比べ応答が大きくなる部分が見られる。この差の 原因としては, 先に行った人工波加振に扔いて大振幅 入力により $\mathrm{EAB}$ 繰返し塑性変形させており, 疲労 により $\mathrm{EAB}$ の剛性が下がり系の固有振動数が低下し たことや，繰返し加振により実験供試体である $\mathrm{EAB}$ の塑性変形の履歷が異なっていることが考えられる。 また，前述のように振動台実験では配管系に加わる入 力加速度が振動台特性の影響を受けたものであるのに 対し，ハイブリッド実験では数值モデルに直接，波形 データ人カしているため, 厳密には入力が一致してい ないことも一因と考えられる。

入力した $\mathrm{E} 1$ Centro 波の最大振幅に対する $\mathrm{EAB} の$ 最大応答変位と最大反力について, ハイブリッド実験 結果と振動台実験結果を比較したものを図 18 に示す。 図中の○印が振動台実験結果を， 印がハイブリッド 実験結果を表しているが, 耐震設計上重要である最大 値の評価沈抢いてほ注等しい值を示すことが確認でき た。

Fig. 17 Response of EAB to El Centro wave (Shaking table) 
5. 結

\section{言}

開発した実時間ハイブリッド実験システムを, $\mathrm{EAB}$ で支持された配管系の振動実験に適用した。EABの 加振実験と配管系の数值計算とを結合した実時間ハイ ブリッド実験の結果を振動台実験の結果と比較するこ とにより，以下に示すような結果を得て，本システム の実用性を確認することができた。

（1）正弦波掃引により得られた配管系の共振点お よび振動伝達特性と, 入力の増加に伴うそれらの変化 は，振動台実験での結果を再現している.

（2）周波数特性の異なる 2 種類の地震波入力に対 する $\mathrm{EAB} の$ 応答波形・履歴, および, 入力振幅と最 大応答の関係は，振動台実験にほ泳等しい結果を示し た。

\section{文献}

（1）伯野元彦・活か2 名, 計算機により制御されたはりの動 的破壞実験，土木学会論文報告集，171(1969-11)，1-9.

（2）家村浩和・ハイブリッド実験の発展と将来, 土木学会論 文集, 356(1985), 1-10.

(3) Takanashi, K. and Nakashima, M., Japaness Activities on On-Line Testing, ASCE, J. Eng. Mech., 113-7 (1987), 1014-1032.

（4）堀内敏彦・ほか 3 名, 加振機の応答遅れを補償した実時 間ハイブリッド実験システムの開発(第 1 報)，機論，61584, C (1995), 1328-1336.

（5）堀内敏彦・ほか 3 名, 加振機の応答遅れを補償した実時 間ハイブリッド実験システムの開発(第 2 報)，機論，62599, C (1996), 2563-2570.

（6）堀内敏彦・ほか1名，加振機の応答遅れを補償した実時 間ハイブリッド実験システムの開発(第 3 報)，機論，64$617, \mathrm{C}(1998)$, 揭載予定.

（7）浪田芳郎・ほか 3 名, 弾塑性ダンパ支持配管系の耐震設 計手法の開発(第 2 報)，機論，61-590，C(1995)，38743880 . 